\title{
Defence cooperation in
}

Europe in the context of the

European Union's Common

Defence and Security Policy:

what has been, will be again?

by Theodore Konstadinides

$\mathrm{T}$ he Treaty of Maastricht (1993) comprised the first effort at EU level towards establishing a European Security and Defence Policy (ESDP). Since then, not only has defence policy cooperation in Europe been formalised - it has further been given a fully-fledged legal body in the Treaty of the European Union (TEU). Today, under the Treaty of Lisbon (2009), Chapter 2, section 2 of the TEU provides the legal framework of the recalibrated Common Security and Defence Policy (CSDP). Lisbon's CSDP has involved measures to strengthen the capacity of European security cooperation by facilitating the crossnational coordination of defence policy. It has also addressed the institutional vacuum of the former ESDP. Yet, the wording of the relevant provisions in the TEU is modest in providing that the progressive framing of CSDP towards common defence constitutes a future possibility.

This short article will attempt to demonstrate the limited development of European defence cooperation within the auspices of CSDP. It will address two key questions, first on the degree of commitment to CSDP that Lisbon generates, and second on the level of integration achieved indirectly through EU coordination of the internal market aspects of the Member States' defence policy in relation to armaments procurement. It is argued that although demonstrating a certain degree of progress, Lisbon's reforms have not pushed towards an integrationist approach transforming, therefore, CSDP to an autonomous operational facility in defence matters. The Member States' reticence to cede full authority to the EU in the field of defence is reflected in the Treaty's wording which leaves intact national sovereignty in relation to military defence. As ever, the EU still relies on Member States and NATO with regard to all defence capability and force generation initiatives in post-Lisbon Europe.

\section{DOES THE TREATY OF LISBON ELUDICATE POINTS OF CONVERGENCE?}

The ambiguity and abstract goals of the CSDP undermine any plans of convergence or defence integration in the forthcoming future. First and foremost, the Treaty of Lisbon lacks a literal definition of "defence." Instead, Article 42 (2) TEU provides two dimensions to "defence" encompassing (i) a mandate for the European Council, acting unanimously, to progressively develop a "common EU defence policy", which will lead to (ii) a "common defence." The second dimension to "defence" is derivative of the first because "common defence policy" falls within EU competence, whilst "common defence" merely comprises an advanced stage of EU integration dependent on political will. As such, depending on one's view, the CSDP either constitutes an up-and-coming policy concentrated on relevant gains or remains a work in progress. But let us see what the terms "common defence policy" and "common defence" imply.

According to Article 43 TEU, CSDP ("common defence policy”) covers a wide array of policy areas ranging from humanitarian and rescue operations to peace-making and post-conflict stabilisation. Lisbon has also played a significant part in augmenting the institutional presence of CSDP by introducing new institutions such as the new post of the High Representative of the EU for Foreign Affairs and Security Policy and her CSDP coordinating role under Article 43 (2) TEU. It has also provided for the institutionalisation of the European Defence Agency (EDA) in order to promote greater cooperation in the field of armaments procurement (Arts 42 (3) and 45 TEU). Inter alia, Lisbon also contains in Article 42 (7) TEU a mutual assistance clause which, rather symbolically, provides that Member States shall assist each other in the event one of their counterparts is attacked. 
No doubt, these reforms offer more than a hint at progress. They have established a system of international cooperation based on voluntariness and consensus but also one based on flexibility and differentiation. This is manifest in the flexibility provisions inserted in Lisbon which provide a small group of Member States with the legal means for launching enhanced cooperation (Art 20 TEU); structured cooperation (Arts 42 (6) and 46 TEU, Protocol 10); as well as unilateral implementation of the so-called Petersberg tasks (Art 44 TEU). Frequent resort to such novel opportunities may undermine the meaning of "common" in CSDP by encouraging the advancement of a two-speed Europe with a hard-core operating beyond the control of the majority of Member States. What is of bigger concern to integrationists is the potential of this hard-core transforming into an avant-garde capable of surviving altogether outside the EU architecture with its own rules of conduct and institutions (see T Konstadinides, (2004), "Now and then: Fischer's Core Europe in the Aftermath of the Collapse of December 2003 Constitutional Talks," vol 11, 1, Irish Journal of European Law 117).

"Common defence", on the other hand, implies the transformation of CSDP to an integrative tool. This is easier said than done, especially since Member States have made it explicit in Lisbon that "in particular, national security remains the sole responsibility of each Member State" (Art 4 (2) TEU). As such, any move towards "common defence" will have to be made by the 27 Member States acting according to 'their constitutional requirements' as per Article 42 (2) TEU. Despite the progress made since Maastricht, the Heads of State in Lisbon remained adamant that state actors still dominate policy agenda-setting and implementation. Hence, the rebranding of the ESDP to CSDP and the change from "European" to "Common" Security and Defence Policy does not imply any alteration on the predominance of the state as the central actor in defence policy formulation and implementation. Neither does Lisbon cast any doubts as to NATO's supreme role in European security. The nature of CSDP remains pretty much an intergovernmental affair where Member States take decisions by unanimity and the Court of Justice of the EU (CJEU) has no jurisdiction to adjudicate upon the limited mandate of CSDP operations.

\section{DOES EU DEFENCE PROCUREMENT CONSTITUTE A STEP TOWARDS COMMON DEFENCE?}

As briefly discussed, the Treaty of Lisbon does not generate initiatives that would compromise national autonomy in military planning (S Blockmans and R Wessel, (2009), "The European Union and Crisis Management: Will the Lisbon Treaty make the EU more Effective?", Journal of Conflict and Security Law, vol 14, 2, 265-308, 305). As such, EU law has concentrated on the place of defence industries at the centre of CSDP. Yet, despite the proliferation of EU collaborative procurement initiatives, there is still way to go for Member States before transferring any decision-making powers to EU institutions. This is because defence procurement consists of a significant part of Member States' public spending and a national competence characterised by a complex legal web regarding the publication of contract notices and selection criteria towards public contracts covering defence products. As such, although public procurement in general falls within the scope of EU law on the prohibition of barriers to free movement, Member States appear reluctant to compromise their own preferences when it comes to defence and therefore include armaments within the framework of EU law (B Heuninckx, (2008), “Towards a Coherent European Defence Procurement Regime? European Defence Agency and European Commission Initiatives", Public Procurement Law Review, vol 17, 1, 1-20).

Despite harmonisation of national procurement laws through EU legislation (see Directive 2009/81/EC and Directive 2009/43/EC) which implies that defence procurement contracts with cross-border interests must comply with EU law, Member States still often resort to a protectionist approach with reference to national defence industries. They seem to have found a way to derogate legitimately from their internal market obligations via automatic reliance to a Treaty exception regarding the scope of EU law. This exception is provided by Article 346 TFEU (former Art 296 EC) which stipulates exceptions for national security reasons in the field of armament production and trade. EU law shall, therefore, not preclude the application of the following rules:

(1) The provisions of the Treaties shall not preclude the application of the following rules:

(a) no Member State shall be obliged to supply information the disclosure of which it considers contrary to the essential interests of its security;

(b) any Member State may take such measures as it considers necessary for the protection of the essential interests of its security which are connected with the production of or trade in arms, munitions and war material; such measures shall not adversely affect the conditions of competition in the internal market regarding products which are not intended for specifically military purposes.

At first glance this elusive list begs the question of what kind of measures can suffice as "necessary" for the protection of national essential security interests connected with the production of or trade in arm. A second reading of Article 346 TFEU provokes even more questions: What falls within or outside the scope of Article 346 TFEU? When is a piece of equipment specifically intended for military purposes? Being an area under which European Courts have competence to adjudicate, the CJEU has clarified matters by emphasising that while Member States are responsible for determining issues regarding the preservation of their national security, there is no general principle excluding procurement matters from the Treaty's scope. The CJEU has further established 
that national practices exempting defence contracts from the scope of EU law can be in breach of the conditions of competition in the internal market similarly to measures regarding products, which are not intended for specifically military purposes (see for detail the recent CJEU judgment of June 7, 2012 in Case C615/10 InsTiimi Oy). Despite this effort by the CJEU to limit the scope of Article 346 TFEU, it will take time for European judges to establish a list as to what is regarded "necessary" for the protection of the Member States' essential interests in every case the exception is relied upon by them.

Member States' freedom to define their own security priorities and shape the essential interests of their national defence has been further shaken by the institutionalisation of the European Defence Agency (EDA) within the legal framework of the CSDP. The EDA's role is not to duplicate existing collaborative armament programmes in Europe but to support the Council and the Member States towards improving EU defence capabilities within a voluntary and non-binding intergovernmental framework. Accordingly, the general rule is that all public contracts have to be put out to tender and would be awarded by the EDA on behalf of the participating Member States. Yet, the EDA has no say over the Member States' essential security interests - it cannot in itself invoke Article 346 TFEU effectively to derogate from the Treaties' application. It can only refrain from complying with the EU procurement framework if Member States decide to invoke Article 346 TFEU in relation to EDA procurement programmes. Hence, the EDA is not yet a defence procurement programme coordinator. It merely manages projects on behalf of the Member States and is controlled by them, operating under the political supervision of the Council and financed by the Member States (see P Koutrakos, "The Role of Law in Common Security and Defence Policy: Functions, Limitations and Perceptions" in P Koutrakos (ed), European Foreign Policy: Legal and Political Perspectives, Edward Elgar, 2011).

\section{CONCLUSION: WHAT HAS BEEN DONE, WILL BE DONE AGAIN?}

The Treaty of Lisbon has not changed the manner in which CSDP policy formulation and execution operates. Policy decisions are still by and large taken unanimously by the EU Member States. Equally, with reference to the interaction of security and defence with the internal market, the Treaty has retained the separation between the "European" and the "national" despite the CJEU's attempts to clear the water vis-à-vis the invocation of Article 346 TFEU. Despite the rise of EU collaborative procurement initiatives, in the absence of structured coordination of national policies, the European armaments market remains fragmented along national lines.

In conclusion, Lisbon's legal limitations are illustrative of the lack of political will to generate concrete cooperative initiatives that indicate a transition from "defence policy" to "defence." Whilst Lisbon has created possibilities for approximation of national practices in the "softer" aspects of security, such as the external dimension of Police and Judicial Cooperation in Criminal Matters, it has fell short of generating cooperation in areas which carry important implications for states' relative power, such as military structures and capability procurement. As such, the utility of CSDP as an effective component of the EU's response to global threats and a means of facilitating cross-national coordination of defence policy remains a diamond in the rough. More research is therefore needed to assess the implications for the future of European defence cooperation, preferably by adopting an interdisciplinary approach that uses the insights of EU law to assess the utility of existing theoretical accounts of European defence cooperation (see T Dyson and T Konstadinides, European Defence Cooperation in EU Law and IR Theory, Palgrave 2013).

\section{Theodore Konstadinides}

Lecturer in Law, University of Surrey. 